\title{
ASSESSMENT OF STREAM QUALITY USING BIOLOGICAL INDICES AT SELECTED SITES IN THE SCHUYLKILL RIVER BASIN, CHESTER COUNTY, PENNSYLVANIA, 1981-97
}

\section{INTRODUCTION}

In 1970, the Chester County Water Resources Authority (Pennsylvania) and the U.S. Geological Survey (USGS) established a longterm water-quality network with the goal of assessing the quality of streams in the county and understanding stream changes in response to urbanization using benthic-macroinvertebrate data (Lium, 1977). This database represents one of the longest continuous water-quality data sets in the country. Benthic macroinvertebrates are aquatic insects, such as mayflies, caddisflies, riffle beetles, and midges, and other invertebrates that live on the stream bottom. Benthic macroinvertebrates are useful in evaluating stream quality because their habitat preferences and low motility cause them to be affected directly by substances that enter the aquatic system. By evaluating the diversity and community structure of benthic-macroinvertebrate populations, a determination of stream quality can be made.

Between 1981 and 1997, the network consisted of 43 sites in 5 major basins in Chester County-Delaware, Schuylkill, Brandywine, Big Elk and Octoraro, and Red and White Clay. Benthic-macroinvertebrate, water-chemistry, and habitat data were collected each year in October or November during base-flow conditions (Reif, 1999; 2000). Using these data, Reif (2002) evaluated the overall water-quality condition of Chester County streams. This Fact Sheet summarizes the key findings from Reif (2002) for streams in the Schuylkill River Basin. These streams include Pigeon Creek (site 10), Stony Run (site 6), French Creek (sites 12-16), Pickering Creek (sites 1-5), Little Valley Creek (site 49), and Valley Creek (site 50) (fig. 1). This summary includes an analysis of stream conditions based on benthicmacroinvertebrate samples and an analysis of trends in stream conditions for the 17-year study period.

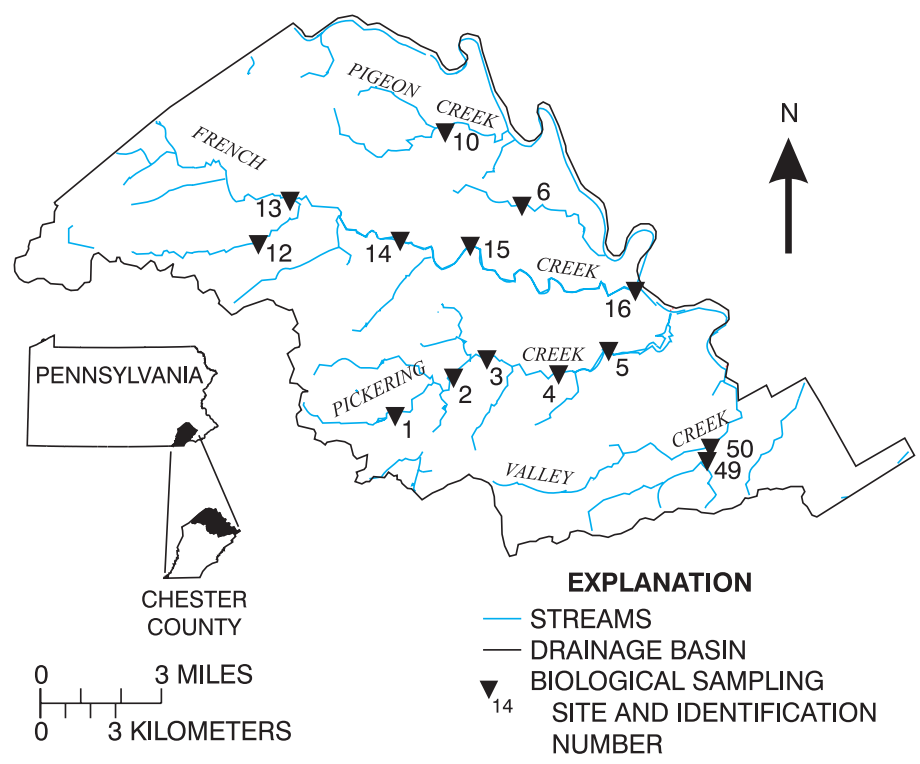

Figure 1. Location of sampling sites in the Schuylkill River Basin, Chester County, Pennsylvania.

\section{STUDY APPROACH}

The analysis of overall stream quality on the basis of benthicmacroinvertebrate sampling uses biological metrics. Each biological metric is a mathematical expression of a different aspect of the benthic-macroinvertebrate community and how it relates to overall stream quality. Each metric provides additional information that can be used to characterize biological responses to water quality over time. The following biological metrics were used in the analysis: taxa richness, Ephemeroptera, Plecoptera, and Trichoptera (EPT) taxa richness, percent EPT, and Hilsenhoff's biotic index (HBI).

Taxa richness is a measure of the number of different kinds of organisms (taxa) in a collection. Richness measures the overall diversity of the biological community sampled. EPT taxa richness is the total number of taxa within the "pollution sensitive" orders Ephemeroptera (mayflies), Plecoptera (stoneflies), and Trichoptera (caddisflies). Taxa richness and EPT taxa richness will decrease with decreasing water quality (Weber, 1973).

The HBI is based on an organism's relative sensitivity to streamquality conditions. The HBI uses assigned tolerance values that range from 0 to 10 . A 0 is assigned to organisms least tolerant of organic pollution, and a 10 is assigned to organisms most tolerant of organic pollution. Species intermediate in their tolerance of organic pollution were assigned intermediate values (Hilsenhoff, 1982). Tolerance values are from the genus- and species-level biotic index developed by the State of New York (Bode, 1991). HBI values from 0 to 4.5 are associated with nonimpacted sites, 4.51 to 6.50 with slightly impacted sites, 6.51 to 8.50 with moderately impacted sites, and 8.51 to 10 with severely impacted sites (Bode, 1993).

\section{STREAM-QUALITY DESIGNATION CRITERIA}

Streams in the network were designated as nonimpacted, slightly impacted, moderately impacted, or severely impacted on the basis of median biological metric values from 1981 to 1997 (table 1). Stream quality refers to the overall condition of the physical habitat, water chemistry, and biological communities in the stream.

Table 1. Stream-quality assessment criteria for Chester County, Pennsylvania, streams (adapted from Bode, 1993)

[EPT, Ephemeroptera, Plecoptera, and Trichoptera; HBI, Hilsenhoff's biotic index; >, greater than]

\begin{tabular}{lccc}
\hline $\begin{array}{c}\text { Stream-quality } \\
\text { assessment }\end{array}$ & $\begin{array}{c}\text { Taxa } \\
\text { richness }\end{array}$ & $\begin{array}{c}\text { EPT taxa } \\
\text { richness }\end{array}$ & $\mathrm{HBI}$ \\
\hline Nonimpacted & $>30$ & $>10$ & $0-4.50$ \\
Slightly impacted & $21-30$ & $6-10$ & $4.51-6.50$ \\
Moderately impacted & $11-20$ & $2-5$ & $6.51-8.50$ \\
Severely impacted & $0-10$ & $0-1$ & $8.51-10$ \\
\hline
\end{tabular}


Nonimpacted: Biological metrics indicate excellent stream quality. The benthic-macroinvertebrate community is diverse, and the community is dominated by "pollution sensitive" and facultative organisms. "Pollution sensitive" organisms include the EPT taxa and generally are intolerant of degraded stream quality. Facultative organisms can survive under a wide range of stream conditions. Water-quality and habitat conditions at nonimpacted sites are not limiting the benthic-macroinvertebrate community. Nonimpacted sites include pristine habitats and those receiving inputs that minimally affect the benthic-macroinvertebrate community.

Slightly Impacted: Biological metrics indicate good stream quality. The benthic-macroinvertebrate community is less diverse than at nonimpacted sites but still contains mayflies, caddisflies, and possibly some stoneflies. The community structure typically is dominated by a few taxa including caddisflies, elmids (riffle beetles), and chironomids. Water-quality and habitat conditions are having an effect on the benthic-macroinvertebrate community. Slightly impacted sites commonly are receiving some wastewater inputs and (or) agricultural/urban runoff.

Moderately Impacted: Biological metrics indicate fair stream quality. The benthic-macroinvertebrate community is disturbed and noticeably altered from a nonimpacted site. Mayflies and stoneflies are rare, and caddisfly taxa may be limited. The benthic-macroinvertebrate community is dominated by "pollution tolerant" and facultative organisms including chironomids and oligochaetes (aquatic earthworms). One or a few groups usually dominate the community. Water- quality and habitat conditions are having a major effect on the benthic-macroinvertebrate community. Moderately impacted sites commonly are receiving heavy wastewater inputs and (or) agricultural/urban runoff.

Severely Impacted: Biological metrics indicate poor stream quality. The benthic-macroinvertebrate community is severely limited with poor diversity. Mayflies, stoneflies, and caddisflies are rare, and the community usually is dominated by chironomids and aquatic earthworms. The community may have low numbers of individuals or high numbers of a few taxa. Severely impacted sites commonly are receiving inputs of a toxin or have extremely low concentrations (less than $4.0 \mathrm{mg} / \mathrm{L}$ ) of dissolved oxygen. Water-quality and habitat conditions are having a severe effect on the benthic-macroinvertebrate community. Severely impacted sites commonly are receiving heavy wastewater inputs and agricultural/urban runoff.

\section{STREAM-QUALITY ASSESSMENT}

The sites sampled in the Schuylkill River Basin range in size from Stony Run, a headwater stream with a drainage area of $2.0 \mathrm{mi}^{2}$ (square miles), to French Creek, with a drainage area of $70.7 \mathrm{mi}^{2}$. Land use in the basin is mixed and includes areas dominated by agriculture, forest, suburban, and urban settings. Stream-quality assessments based on calculated biological metrics are presented in table 2 and figure 2 .

Table 2. Designation of water quality and median values of taxa richness, EPT taxa richness, Hilsenhoff's biotic index, and median values of percentage of EPT individuals for sites in the Schuylkill River Basin, Chester County, Pennsylvania, 1981-97 [EPT, Ephemeroptera, Plecoptera, Trichoptera]

\begin{tabular}{|c|c|c|c|c|c|}
\hline $\begin{array}{c}\text { U.S. Geological } \\
\text { Survey station } \\
\text { identification number }\end{array}$ & $\begin{array}{c}\text { Site } \\
\text { number }\end{array}$ & Taxa richness & $\begin{array}{c}\text { EPT taxa } \\
\text { richness }\end{array}$ & $\begin{array}{l}\text { Hilsenhoff's } \\
\text { biotic } \\
\text { index }\end{array}$ & $\begin{array}{c}\text { Percentage } \\
\text { of EPT } \\
\text { individuals }\end{array}$ \\
\hline \multicolumn{6}{|c|}{ Pigeon Creek } \\
\hline & & Nonimpacted & Nonimpacted & Nonimpacted & \\
\hline 01472080 & 10 & 33 & 20 & 4.28 & 69 \\
\hline \multicolumn{6}{|c|}{ Stony Run } \\
\hline & & Nonimpacted & Nonimpacted & Slightly impacted & \\
\hline 01472109 & 6 & 34 & 16 & 4.66 & 61 \\
\hline \multicolumn{6}{|c|}{ French Creek } \\
\hline & & Nonimpacted & Nonimpacted & Slightly impacted & \\
\hline 01472138 & 13 & 34 & 20 & 4.58 & 49 \\
\hline & & Nonimpacted & Nonimpacted & Nonimpacted & \\
\hline 01472140 & 12 & 35 & 24 & 4.15 & 73 \\
\hline & & Nonimpacted & Nonimpacted & Nonimpacted & \\
\hline 01472154 & 14 & 34 & 21 & 4.28 & 74 \\
\hline & & Nonimpacted & Nonimpacted & Nonimpacted & \\
\hline 01472157 & 15 & 35 & 20 & 3.86 & 76 \\
\hline & & Slightly impacted & Slightly impacted & Slightly impacted & \\
\hline 014721612 & 16 & 22 & 7 & $5.44^{1}$ & 19 \\
\hline \multicolumn{6}{|c|}{ Pickering Creek } \\
\hline & & Slightly impacted & Nonimpacted & Slightly impacted & \\
\hline 01472170 & 1 & 27 & 15 & $5.05^{\circ}$ & 59 \\
\hline & & Slightly impacted & Nonimpacted & Nonimpacted & \\
\hline 01472174 & 2 & 26 & 16 & 3.99 & 70 \\
\hline & & Nonimpacted & Nonimpacted & Slightly impacted & \\
\hline 014721854 & 3 & 31 & 19 & 4.73 & 48 \\
\hline & & Nonimpacted & Nonimpacted & Slightly impacted & \\
\hline 014721884 & 4 & 37 & 22 & 4.65 & 68 \\
\hline & & Nonimpacted & Nonimpacted & Slightly impacted & \\
\hline 01472190 & 5 & 35 & 22 & 4.74 & 67 \\
\hline \multicolumn{6}{|c|}{ Little Valley Creek } \\
\hline & & Moderately impacted & Slightly impacted & Nonimpacted & \\
\hline 01473167 & 49 & 17 & 7 & 4.03 & 64 \\
\hline \multicolumn{6}{|c|}{ Valley Creek } \\
\hline 01473168 & 50 & $\begin{array}{l}\text { Slightly impacted } \\
21\end{array}$ & $\begin{array}{l}\text { Slightly impacted } \\
8\end{array}$ & $\begin{array}{l}\text { Slightly impacted } \\
5.08\end{array}$ & 30 \\
\hline
\end{tabular}




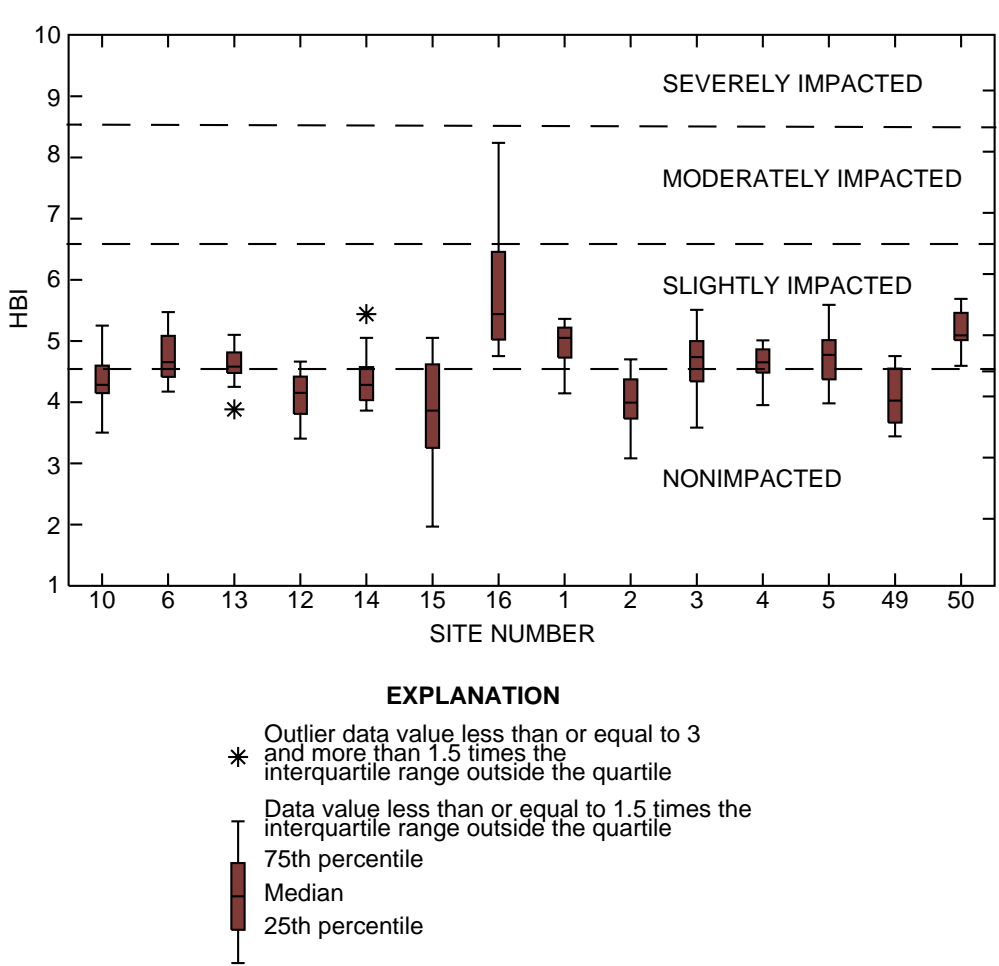

Figure 2. Hilsenhoff's biotic index (HBI) values from sites in the Schuylkill River Basin, Chester County, Pennsylvania, 1981-97.

Pigeon Creek (site 10) was designated as nonimpacted on the basis of calculated biological metrics (table 2). The benthic-macroinvertebrate data collected at this site indicate a diverse and stable benthic-macroinvertebrate community with numerous "pollution sensitive" organisms. Field observations and chemical data collected in conjunction with the benthic-macroinvertebrate samples indicate stable habitat, water chemistry, and biological conditions.

The benthic-macroinvertebrate community in Stony Run (site 6) is designated as mostly nonimpacted on the basis of the calculated biological metrics (table 2). The data indicate diverse and consistent populations of "pollution sensitive" organisms and occasionally large numbers of "pollution tolerant" organisms. The presence of these "pollution tolerant" organisms in large numbers can be an indication of organic pollution. Field observations and chemical data collected in conjunction with the benthic-macroinvertebrate samples indicate degraded habitat caused by siltation and slightly elevated nitrate concentrations (median concentration $4.0 \mathrm{mg} / \mathrm{L}$ (milligrams per liter)) when compared to other sites in the Schuylkill River Basin. Nitrate concentrations ranged from 2.4 to $6.5 \mathrm{mg} / \mathrm{L}$ at site 6 but were below $3.0 \mathrm{mg} / \mathrm{L}$ at all other sites in the Schuylkill River Basin. Stony Run maintains a diverse benthic-macroinvertebrate community in an area dominated by agricultural land use.

The benthic-macroinvertebrate data collected from French Creek upstream from the Borough of Phoenixville (sites 12-15) indicate a mostly nonimpacted (table 2) and diverse and stable benthic-macroinvertebrate community with numerous "pollution sensitive" organisms including a large and diverse stonefly population. Field observations and chemical data collected in conjunction with the benthic-macroinvertebrate samples indicate no adverse effects of habitat alteration, siltation, or nutrient enrichment. Median concentrations of nitrate $(1.2 \mathrm{mg} / \mathrm{L})$, ammonia $(0.2 \mathrm{mg} / \mathrm{L})$, and organophosphate $(0.1 \mathrm{mg} / \mathrm{L})$ were among the lowest measured throughout Chester County.

The benthic-macroinvertebrate community at site 16 was degraded compared with upstream sites (table 2). Influences from urban land use appear to be the cause of the degradation. Site 16 is near the confluence with the Schuylkill River and is in the Borough of Phoenixville. The benthic-macroinvertebrate data collected from this site had lower taxa richness and EPT taxa richness and higher HBI values than the other sites on French Creek, indicating decreased stream quality (fig. 2). Chemical data indicate site 16 has similar water-quality conditions when compared to the other sites in the French Creek Basin but field observations of habitat conditions indicate erosion is more severe at site 16 . The site also was subject to increased concentrations of metals prior to 1982. Concentrations declined after 1982 and EPT taxa increased, indicating improved water-quality conditions (fig. 3). However, the number of EPT taxa remains lower than other sites in the French Creek Basin.

The benthic-macroinvertebrate data collected from the sites on Pickering Creek (sites 1-5) indicate a nonimpacted to slightly impacted and diverse but variable benthic-macroinvertebrate community with numerous "pollution sensitive" organisms including large and diverse stonefly and mayfly populations. Biological metrics indicate steady or slightly improving stream conditions in Pickering Creek from 1986 to 1997. Physical and chemical data collected in conjunction with the benthic-macroinvertebrate samples indicate stable habitat and consistent water chemistry, except for ammonia concentrations. All sites in the basin had elevated ammonia concentrations from 1983 to 1984 and then declined in 1985 and remained low. Sites 1-4 had increased numbers of taxa after 1985 when the lower ammonia concentrations were measured (fig. 4). Ammonia consumes oxygen as it is oxidized from ammonia to nitrate. Therefore, decreased ammonia concentrations reduce toxicity and can lead to increased dissolved oxygen concentrations (U.S. Geological Survey, 1999), which will affect the benthic macroinvertebrates positively. Decreased ammonia also reduces toxicity.

Valley Creek (site 50) and Little Valley Creek (site 49) are both slightly impacted (table 2) and have benthic-macroinvertebrate communities with reduced numbers of taxa and EPT taxa when compared to the other sites in the Schuylkill River Basin. Valley and Little Valley Creeks are streams flowing over limestone that have naturally high specific conductance and alkalinity. The low numbers of taxa and EPT taxa that indicate the streams are slightly to moderately impacted may be because the basins have greater than 10 percent impervious surfaces and (or) because of naturally occurring conditions in a stream overlying limestone. Although the number of taxa is low, the benthicmacroinvertebrate community at site 49 contains a high percentage of "pollution sensitive" organisms, and the benthic-macroinvertebrate community at site 50 contains a high percentage of "pollution tolerant" organisms (fig. 5). The decreased stream quality in Valley Creek may be associated with degraded habitat from sedimentation.

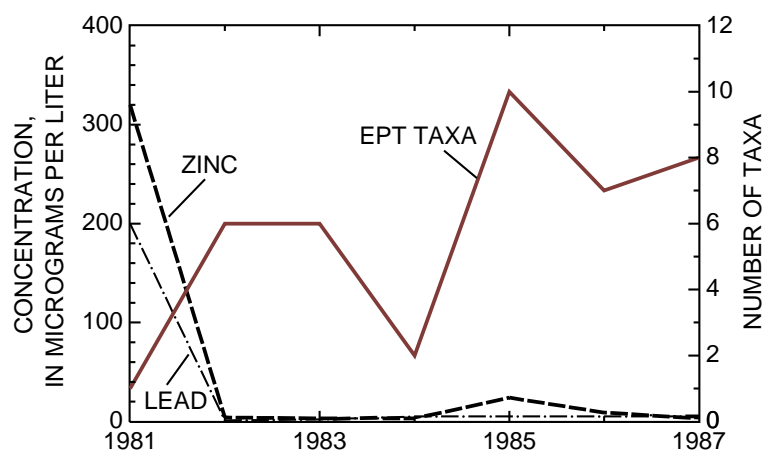

Figure 3. Concentrations of zinc and lead and Ephemeroptera, Plecoptera, Trichoptera (EPT) taxa values from French Creek at Phoenixville (site 16), Chester County, Pennsylvania, 1981-87. 


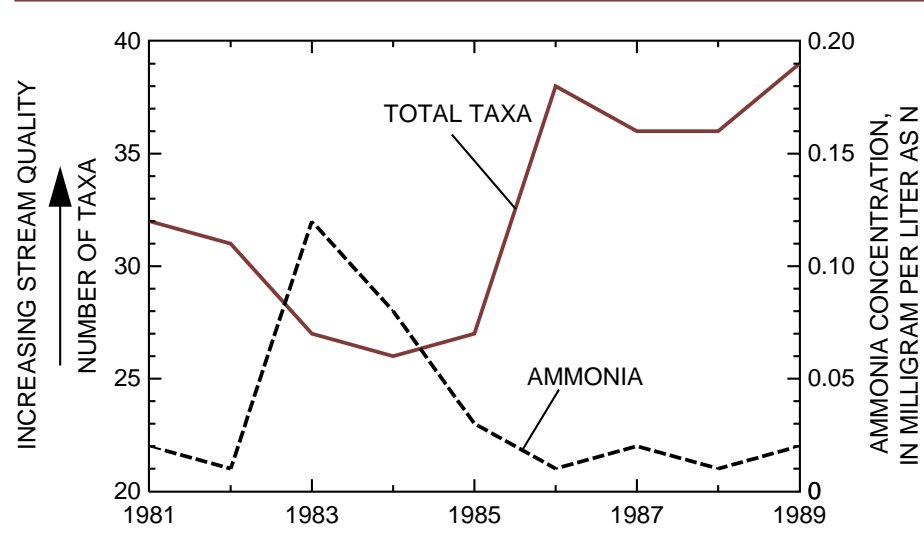

Figure 4. Total taxa and ammonia concentration at Pickering Creek at Charlestown (site 4), Chester County, Pennsylvania, 1981-89.

\section{TRENDS IN BENTHIC- MACROINVERTEBRATE AND CHEMICAL DATA}

The Mann-Kendall test was used to detect trends from 1981 through 1997 in HBI values at the sites in the Schuylkill River Basin (Helsel and Hirsch, 1997). A decreasing trend in HBI values indicates improving stream quality, and an increasing trend indicates deteriorating stream quality.

Three of the 14 sites (sites 1, 16, and 50) had a statistically significant decreasing trend in HBI values. The improvement in stream quality indicated by the decreasing HBI values at sites 1, 16, and 50 is associated with declining concentrations of phosphorus and ammonia similar to those noted at site 4 (fig. 4). The declining trend in ammonia and phosphorus was detected at most sites in the Schuylkill River Basin, although it was statistically significant at only four sites. The improved stream quality at site 16 in French Creek occurred after a reduction in dissolved metal concentrations (fig. 3). Site 50 in Valley Creek had improved stream quality associated with a decline in PCB and organochlorine pesticide concentrations from 1981 to 1997. Ten sites in the basin had nonsignificant trends indicating stable stream quality. Site 2 on Pickering Creek was the only site with a statistically significant increasing trend in HBI values, which indicates deteriorating stream quality. Decreased stream quality at site 2 can be attributed to unstable stream-bottom habitat, potentially from increased peak flows caused by urbanization.

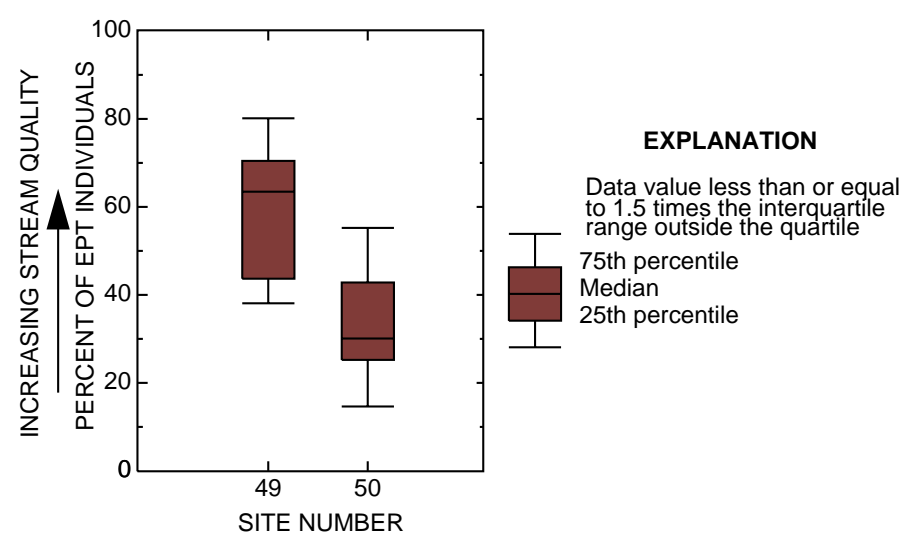

Figure 5. Percent of Ephemeroptera, Plecoptera, Trichoptera (EPT) individuals from Little Valley (site 49) and Valley Creek (site 50), Chester County, Pennsylvania, 1981-97.

\section{SUMMARY}

The assessment of benthic-macroinvertebrate communities in the Schuylkill River Basin in Chester County, Pa., indicates most sites in Pigeon, French, and Pickering Creeks support water quality and habitat conditions that are not limiting the benthic-macroinvertebrate communities. Streams sampled in the basin by the U.S. Geological Survey, in cooperation with the Chester County Water Resources Authority, have low nutrient concentrations and stable habitats. Altered habitat from siltation and slight nutrient enrichment may be degrading stream quality in Stony Run. Sites in the Valley Creek Basin have reduced numbers of taxa possibly related to the basins having greater than 10 percent impervious surfaces and (or) because of naturally reduced macroinvertebrate communities typically found in streams flowing over limestone. Trend analysis indicates stable or increasing stream quality along with relatively low and decreasing concentrations of nitrate, ammonia, and phosphorus at most sites in the Schuylkill River Basin.

\section{-Andrew G. Reif}

\section{REFERENCES CITED}

Bode, R.W., 1991, Quality assurance work plan for biological stream monitoring in New York State: New York Department of Environmental Conservation Technical Report, $79 \mathrm{p}$.

1993, 20 year trends in water quality of rivers and streams in New York State on the basis of macroinvertebrate data 1972-1992: New York Department of Environmental Conservation Technical Report, $196 \mathrm{p}$.

Helsel, D.R., and Hirsch, R.M., 1997, Statistical methods in water resources: New York, Elsevier Science Publishing Co., Inc., 529 p.

Hilsenhoff, W.L., 1982, Using a biotic index to evaluate water quality in streams: Wisconsin Department of Natural Resources Technical Bullestreams: Wisconsin
tin, no. 132,22 p.

Lium, B.W., 1977, Limnological studies of the major streams in Chester County, Pennsylvania: U.S. Geological Survey Open-File Report 77-462, $37 \mathrm{p}$.

Reif, A.G., 1999, Physical, chemical, and biological data for selected streams in Chester County, Pennsylvania, 1981-94: U.S. Geological Survey Open-File Report 99-216, 607 p.

2000, Physical, chemical, and biological data for selected streams in Chester County, Pennsylvania, 1995-97: U.S. Geological Survey OpenFile Report 00-238, $146 \mathrm{p}$.

2002, Water-quality assessment and trends in biological and water quality data from selected streams in Chester County, Pennsylvania, 1981-97: U.S. Geological Survey Water-Resources Investigations Report 02-4242, 78 p.

U.S. Geological Survey, 1999, The quality of our nation's waters-Nutrient and pesticides: U.S. Geological Survey Circular 1225, 82 p.

Weber, C.I., ed., 1973, Biological field and laboratory methods for measuring the quality of surface waters and effluents: Cincinnati, Ohio, U.S. Environmental Protection Agency, EPA-670/4-73-001.

\section{For additional information, contact:}

District Chief

U.S. Geological Survey, WRD

215 Limekiln Road

New Cumberland, PA 17070-2424

(717) $730-6913$

http://pa.water.usgs.gov

Chester County Water Resources Authority

Government Services Center

601 Westtown Road

West Chester, PA 19382-4537

(610) 344-5400

http://www.chesco.org/water/index.html 